\title{
Technological Change from Foreign Firms: Firm-Level Case Studies in the Kenyan Context
}

\author{
Geoffrey G. Gachino ${ }^{1}$ \\ ${ }^{1}$ Economics and Statistics Department, College of Business Admnistration, University of Dubai, Dubai, United \\ Arab Emirates \\ Correspondence: Geoffrey G. Gachino, Economics and Statistics Department, College of Business \\ Admnistration, University of Dubai, P.O. Box 14143, Dubai, United Arab Emirates. E-mail: \\ Geoffrey.gachino@gmail.com; ggachino@ud.ac.ae
}

$\begin{array}{ll}\text { Received: December 12, } 2011 & \text { Accepted: February 25, } 2012 \\ \text { doi:10.5539/ijbm.v7n9p158 } & \text { URL: http://dx.doi.org/10.5539/ijbm.v7n9p158 }\end{array}$

\begin{abstract}
Foreign direct investment and technological spillovers are among the most widely studied to understand their role in learning, capability building and innovation management. The purpose of this paper is to examine the role of FDI in industrial development in the sub Saharan region but using an alternative framework taking Kenya as a case study country. Specifically, the paper investigates whether presence of FDI in manufacturing industry stimulates spillover occurrence. This is done following a unique analytical framework developed taking into consideration human resource development, linkages, competition and demonstration effects. On the basis of this framework, foreign presence stimulated spillover occurrence in Kenya's industry. There was tremendous evidence of learning, capability building and innovation due to spillover occurrence. The main limitation of this paper is that results obtained cannot be generalized since the five foreign firms studied cannot be considered comprehensive representatives of the entire manufacturing industry. The results need to change our thinking with regard to policy pertaining to the role FDI plays in a host country's industrial development. This paper presents the only known work based in Africa focusing on FDI, spillovers, learning, capability building and innovation. The case studies, though ambitious, present findings which need to change our thinking about the past results and methodologies of the past studies on FDI and spillovers.
\end{abstract}

Keywords: foreign direct investment, technological spillovers, technological innovation, technological learning, Kenya

\section{Introduction}

Foreign direct investment (FDI) remains one of the most widely studied topics in development economics discourse. From a technical change perspective, technological spillovers can contribute towards industrial development through learning, capability development and innovation [Marshall, 1890; Schumpeter, 1934; Arrow, 1962; Griliches, 1979; Romer, 1986; Aghion and Howitt, 1990; Rasiah, 2005; Gachino, 2010a]. Limited convincing work exists to ascertain this empirically basing their argument and logic on appropriate techniques. Existing studies on FDI and spillovers have largely been based on the traditional neo-classical approach focusing on cross sectional data and limited to labour productivity [Caves, 1974; Blomstrom and Pearsson, 1983; Aitken and Harrison, (1992: 1996), Ruane, et al., 2004; Haskel et al., 2007; Kravtsova, 2008; Altomonte et al., 2009; Görg, et al., 2009; Gachino, 2010b]. This is problematic in that the neo-classical approach has failed to maintain pace with the growing importance of learning, capability building and innovation in technology development for economic growth. Also studies based on this approach have remained inconclusive with some supporting occurrence of spillovers and others not (Görg and Greenaway, 2004; Gachino, 2006; Crespo, 2007; Wang and You, 2007; Meyer, 2009).

This paper investigates whether presence of FDI in manufacturing industry stimulates spillover occurrence. This is done by adopting a wider stance reconceptualising spillovers in terms of learning, capability building and innovation at the firm level. This is largely Schumpeterian based [Schumpeterian, (1934: 1952); Arrow, 1962; Romer, 1990; Aghion and Howitt, 1990; Hansen, 2002; Cheng and Lin 2004; Rasiah, 2005]. The actual analytical framework developed takes into consideration human resource development, linkages, competition 
and demonstration effects. All these are believed to be avenues through which such spillovers can occur. On the basis of this framework, this paper presents five detailed case studies of foreign firms operating in the Kenyan Manufacturing industry to illustrate the spillover process. This is intended to make a more comprehensive and qualitative examination of spillovers and thus supplement the empirical findings obtained in the past studies.

This paper is divided into five sections. Section 2 presents framework of analysis. In section 3, a brief analysis of foreign firms is presented. Section 4 presents the case studies in food and beverages. Section 5 presents summary and conclusions.

\section{Framework of Analysis}

Productivity technique has been criticised due to its inherent weaknesses in examining the spillover process (Gachino, 2010a). An alternative analytical framework is proposed which enables a rich examination of spillovers on the basis of occurrence mechanism, kinds and determinants.

On the basis of this framework, the spillover process is perceived to involve activities (e.g. technological and innovation) in both foreign and local firms. However, in this paper, we will provide individual accounts of foreign firms only following case study approach. It should be pointed out from the onset that this exercise is not meant to quantify the amount of spillovers occurring nor is it meant to determine who generates more spillovers than the other. This paper provides a qualitative illustration of the spillover process - e.g. by looking at the ways in which presence of foreign firms opens opportunities for technological spillovers. A new analytical method introduced here, therefore, takes into consideration four concepts perceived to improve our understanding of the less understood spillover process in the context of least developed countries particularly those in the sub Saharan Africa. Kenya is selected for this study due to its relatively mature manufacturing industry with an early entry of FDI which is believed to have been a major driver of the industrial progress so far achieved.

We now address the four aspects of the proposed analytical framework starting with human resource development (see Figure 1). First, the case study makes an intensive examination of human resource development (training) undertaken in foreign firms. This is important due to the direct relationship it has with spillover occurence. For instance, we can only expect spillovers due to mobility of staff from foreign firms if foreign firms have strong measures in place on human resources development. Thus, we tried to examine the kind of training offered to the local personnel and its usefulness to their firms. Foreign firms are claimed to offer more training than locally owned firms. We equally attempted to understand the extent to which the training done, including other forms of skill enrichment programmes offered, might have resulted in accumulation of capability necessary to manage and operate production technology in the firms.

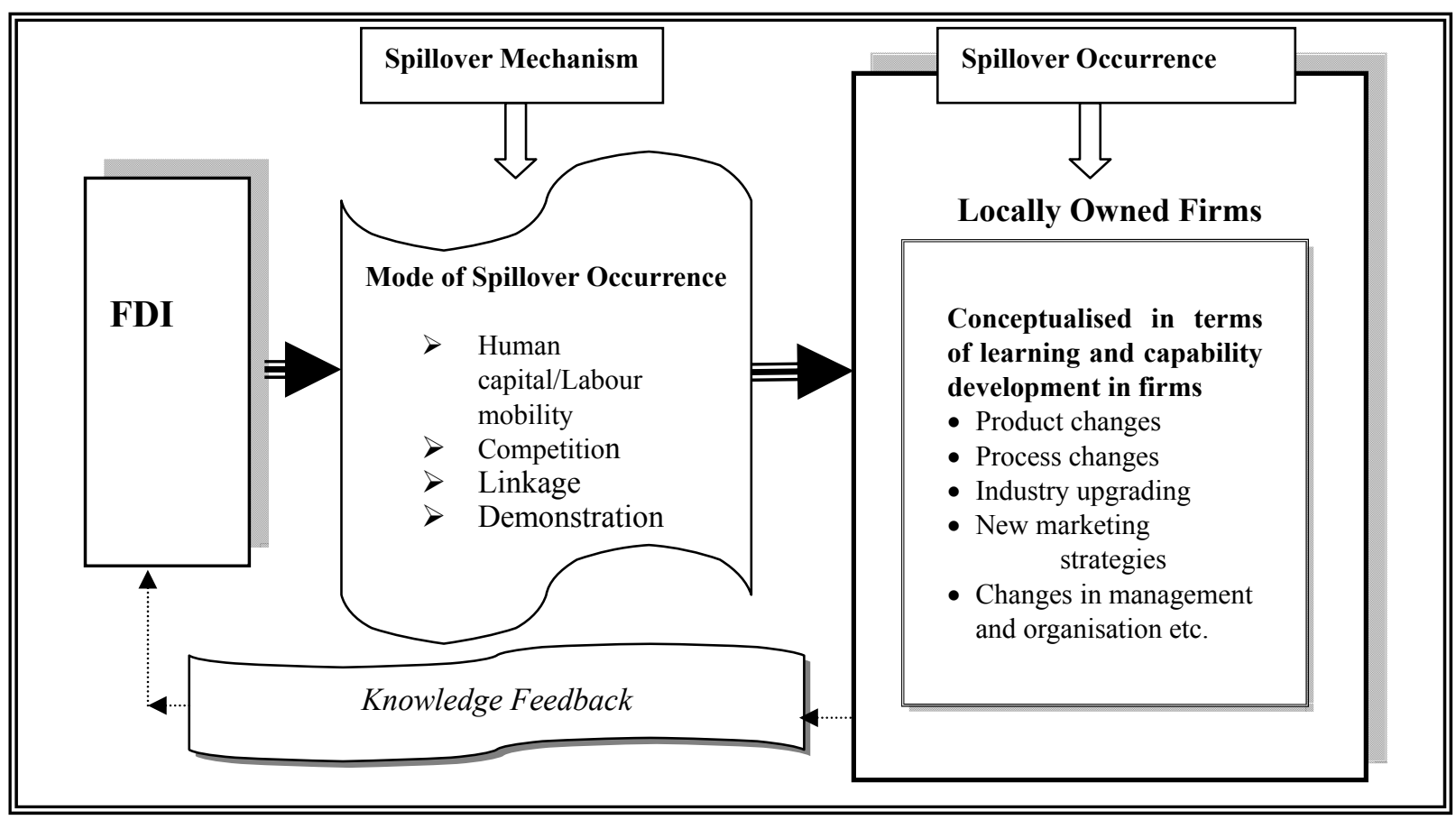

Figure 1. Analytical framework: towards understanding the spillover process

Source: Author 
Additionally, we investigated whether the acquired experiential and tacit knowledge resulted in any hierarchical or upward mobility with regard to the local personnel. In order to understand whether technological skills and experiential knowledge acquired in foreign firms were transferred to the locally owned firms, considerable effort and time was put to examine labour mobility in foreign firms. Cases of mobility have been identified to result in technological spillovers (Gerschenberg, 1987; Behrman and Wallender, 1976; Pack, 1993; Ernst, Mytelka and Ganiatsos, 1998; Fosfuri, Massimo and Ronde, 2001; Glass and saggi, 2002; Blomstrom and Kokko, 2003; Sinai, 2004; Inzelft, 2008). All these investigations were intended to provide insight as to whether foreign firms participated in the human capital development effort in manufacturing.

Second, we studied extensively various kinds of linkages formed by foreign firms. Linkages between MNCs and domestic firms are believed to be a strong mechanism of spillover occurrence [Hirschman, 1958; Lall, 1987; Rodriguez-Clare, 1996; Altenburg, 2000; UNCTAD, 2002; Belderbos, Capannelli and Fukao, 2001; Smarzynska, 2003; Javorcik, 2004; Giroud and Scott-Kennel, 2007; Scott-Kennel, 2007; Kneller, 2007; Muraközy, 2007; Marcin, 2008]. We mapped out the linkages and networks that existed between MNC and say the indigenous firms, institutions and business associations. The two classifications of linkages known to exist include pecuniary and non-pecuniary linkages. In both cases, forward and backward linkages can be traced. Pecuniary linkages differ from non-pecuniary linkages in that the former is considered to be purely monetary in nature. We examined the extent to which pecuniary linkages are formed.

Further to the business advantages, pecuniary linkages are likely to be useful to the foreign firms in view of the feedback obtained which helps them make improvements on their products, processes, organisation and marketing approach. We also attempted to find out how pecuniary linkages formed with locally owned firms might have helped the growth and development of locally owned firms by providing them with capital to finance technology, machinery and equipment etc. The demand or supply created by these MNCs sometimes creates new opportunities for locally owned firms to make improvements and/or introduce new investments. Non-pecuniary linkages were also studied. They included machine and engineering linkages (user-supplier relationships) and technical assistance through interactions with the local support systems such as business associations and institutions such as R\&D/academic and financing institutions.

Third, competition between foreign firms and local firms was also extensively examined. This was done by investigating foreign firms in industrial sectors where MNCs were in competition with locally owned firms either for raw materials or markets. This is important in order to investigate the sources, intensity and effect of competition pressure. Competition between foreign and domestic firms creates pressure, which forces local firms to learn and build capabilities (Caves, 1982; Das, 1987; Wang and Blomstrom, 1992; Rasish, 2005; Rasiah and Gachino, 2005; Jarvocik and Spatareanu, 2008). We examined technological changes undertaken by foreign firms as a result of this competition. This also helps us understand how local firms react to competition pressure from foreign firms in such industrial sectors making them survive. This could serve as a trigger effect to both kinds of firms reflecting occurrence of spillovers of knowledge, learning and capability building.

Fourth, in weak developing countries, locally owned firms have been known to benefit from substantial demonstration effects from foreign firms or imported machinery and technology as witnessed in the Newly Industrialised Countries in East Asian countries [ Fransman, 1985; Lall, 1996; Kim, (1997:1999); Ernst, Mytelka and Ganiatsos, 1998; Rasiah, 2003; Cheung and Lin, 2004; Gachino, 2006; Costantini, 2011]. This was unlikely to be absent and had not received any attention in the Kenyan manufacturing industry. Thus as a fourth element, we examined the extent to which foreign firms offered directly or indirectly to demonstrate their products, processes, marketing skills, management and organisation etc to the locally owned firms. We attempted to find out from them whether their processes or products had been copied and/or imitated by the locally owned firms and if so to what extent that had resulted in learning, capability building and innovation.

The foreign firms included in the case study were selected on the basis of the descriptive and empirical analysis done based on the data collected from the firm level survey. Five firms were selected -3 Wholly Owned Firms and 2 Joint Ventures - in the food and beverages industry. The firm selection criterion was based on the nature of production technology as well as learning and innovation observed in the firms. The case study involved face-to-face interviews with production managers and general scientists \& engineers [mechanics, technicians, artisans, craftsmen \& maintenance crew] using semi-structured questionnaires comprising both closed and open-ended questions. The engineers provided information on technology while managers provided information on how prevailing government policies and incentive systems in Kenya influenced company's strategies. In most cases, the MNCs allowed us at least a day to view their production processes and acquaint ourselves with the machinery and technology utilised right from raw material reception, processing line to warehousing. This created an opportunity to discuss openly with a wide cross-section of staff. 


\section{Brief Analysis of the Firms: Background and General Information}

As indicated, five foreign owned firms were interviewed. FBF1, FBF3 and FBF4 were wholly owned affiliates of foreign MNCs while the rest were joint ventures. FBF1, FBF2 and FBF4 firms were relatively old firms having been established in Kenya before her independence in 1963 (Table 1). FBF3 were established in 1970s while FBF5 was established in 1980s. All the five firms are classified as large scale firms by Kenya's manufacturing industry standard. FBF1 manufactures a wide range of foods, home and personal care products. FBF2 is involved in the production and distribution of alcoholic beverages, malt and glass while FBF3 manufactures beverages, infant food products and culinary products. FBF4 deals with extensive farming and agro-processing of fruits mainly pineapples and passion fruits for exports. FBF5 manufactures and distributes carbonated brands of Cola, packages mineral water and a variety of fresh fruit juices.

Table 1. Basic data and information on foreign firms studied, Kenya

\begin{tabular}{|c|c|c|c|c|c|c|c|c|c|c|c|}
\hline Firm Code & $\begin{array}{c}\text { Year } \\
\text { Established }\end{array}$ & $\begin{array}{c}\text { \% of } \\
\text { Capacity } \\
\text { Utilised }\end{array}$ & $\begin{array}{l}\text { Number of } \\
\text { Employees } \\
\text { (Expatriates) }\end{array}$ & $\begin{array}{l}\text { Professional } \\
\& \\
\text { Technicians }\end{array}$ & $\begin{array}{c}\text { MNC } \\
\text { Affiliate }\end{array}$ & $\begin{array}{c}\text { \% Foreign } \\
\text { Ownership } \\
\text { Country }\end{array}$ & $\begin{array}{l}\text { Main Product(s) } \\
\text { Manufactured }\end{array}$ & $\begin{array}{c}\text { Appr. } \\
\text { Sales } \\
\text { Turnover } \\
\text { (Mn } \\
\text { KShs) }\end{array}$ & $\begin{array}{c}\% \quad \text { of } \\
\text { Sales } \\
\text { Exported }\end{array}$ & $\begin{array}{l}\text { Main Export } \\
\text { Destination }\end{array}$ & $\begin{array}{l}\text { R\&D } \\
\text { (\% of } \\
\text { Sales) }\end{array}$ \\
\hline \multicolumn{12}{|c|}{ Food and Beverages } \\
\hline FBF1 & 1953 & 82 & $1,265(15)$ & 53 & Yes & $\begin{array}{l}100 \\
\text { Britain/Dutch }\end{array}$ & $\begin{array}{l}\text { Food; Homecare and Personal } \\
\text { care products }\end{array}$ & 8,035 & 25 & $\begin{array}{l}\text { East \& Central } \\
\text { Africa, Europe }\end{array}$ & 0.26 \\
\hline FBF2 & 1922 & 80 & $1474(20)$ & 28 & $\begin{array}{c}\text { Joint } \\
\text { Venture }\end{array}$ & $\begin{array}{l}54 \\
\text { Ireland }\end{array}$ & $\begin{array}{l}\text { Beer, Wines and Spirits, Malt } \\
\text { and Glass }\end{array}$ & 27,700 & 34 & $\begin{array}{l}\text { COMESA, } \\
\text { (Africa), } \\
\text { Europe, USA, } \\
\text { Canada }\end{array}$ & 0.80 \\
\hline FBF3 & 1970 & 80 & $430(4)$ & 30 & Yes & $\begin{array}{c}100 \\
\text { Switzerland }\end{array}$ & $\begin{array}{l}\text { Milo, Chilli, Milk Products } \\
\text { (Culinary products) }\end{array}$ & 5,968 & 48 & $\begin{array}{l}\text { COMESA } \\
\text { Countries, } \\
\text { Europe }\end{array}$ & 0.23 \\
\hline FBF4 & 1948 & 70 & $2,720(20)$ & 15 & Yes & $\begin{array}{l}100 \\
\text { Italy }\end{array}$ & $\begin{array}{l}\text { Pineapples, fruit juice e.g. } \\
\text { passion }\end{array}$ & 4,968 & 98 & Europe \& USA & 0.46 \\
\hline FBF5 & 1987 & 80 & $714(40)$ & 10 & $\begin{array}{c}\text { Joint } \\
\text { Venture }\end{array}$ & $\begin{array}{c}72 \\
\text { USA/S } \\
\text { Africa }\end{array}$ & $\begin{array}{l}\text { Soft Drinks, mineral water, } \\
\text { fruit juice }\end{array}$ & 6,300 & 40 & $\begin{array}{l}\text { COMESA } \\
\text { countries }\end{array}$ & 0.37 \\
\hline
\end{tabular}

\section{The Case Studies of Foreign Firms in the Food and Beverage Industry}

In this section, we outline in detail the selection procedure for each of the firms considered.

\section{Firm Selection and Justification: Emphasis on Production Technology, Learning and Innovation}

As pointed out the choice of firms to be studied was based on production technology, learning and innovation. In this section we now turn to individual case studies and explain why they were specifically selected.

FBF1 was the most advanced firm in its sector. It uses completely foreign technology for its manufacturing activities. Given its wide set of manufactured products, FBF1 operated many processing lines and had several refineries located in different cities. The firm utilised over $80 \%$ of its total capacity installed. In 1989, FBF1 installed a major edible-oil refinery sourced from Germany. The installation was done by the suppliers - a German firm - who were at the time among the world leaders in the supply and installation of edible oil refineries. This was a sophisticated plant whose processing technology was computer controlled comparable to those used in Europe. The plant consisted of three main components: a continuous deodorising - stripping plant, pre-treatment equipment and an oil blending system. The continuous deodorising was the most innovative component introduced in the new plant which enabled a continuous process as opposed to the conventional batch type used before. With the innovation introduced, FBF1 was capable of deodorising different types of vegetable oils at high quality level.

The second component of the plant serves to pre-treat oil by removing unwanted colour and any traces of metal ions present before it was fed through the deodorising column. This process innovation had actually been patented by the parent company. At the time of installation, FBF1 was among the first subsidiaries to utilise it. The third innovation was a sophisticated oil-blending component that enabled FBF1 to produce many blends of oil. The advantage of production technology introduced was capacity expansion and flexibility enhancement. The flexibility of the process enabled rapid introduction of product changes as dictated by dynamics in the market - changing consumer tastes and preferences such as changes in shape, sizes and packaging. Products of meeting international quality standards could be produced.

Turning to the training and learning acquired from the refinery process, the firm indicated that both training and learning commenced with the installation of the refinery and were a continuous process. Locals were involved in 
the entire process from plant installation to commissioning. The local personnel involved included senior managers, production and machine operators, and engineers and technicians from the engineering and maintenance department. Note also that earlier, a few engineers had been sent for training abroad to acquire experience with the machine suppliers. The engineers from the suppliers spent several weeks introducing locals to all the stages through formal trainings and in the form of discussion forums. A lot of emphasis was attached to production operations and routine maintenance. Much time was therefore spent with the production operators (machine operators) and the engineers and technicians who would later ensure that the operations of the installed machinery and equipment were smooth and efficient. Tremendous production capability had been built. Over time the engineering and maintenance department had accumulated capability and could handle most types of trouble shootings, make minor modifications, undertake major overhaul and do maintenance and repair most of the plant components. An international link is maintained with machinery suppliers for consultations and technical support in cases of major breakdown.

The product technologies used in this firm were also fully foreign. The firm did not involve itself with serious search of product technology. The search activities to introduce new or improve the products were left with the parent company abroad. In actual fact, the firm confirmed that the parent company was the main driver of product technological knowledge and innovation. Nevertheless, the firm spends a substantial amount of money on R\&D which is only in quality control, materials and chemical analysis. This money is spent adopting the international products to the local conditions, tastes and preferences. This supports the fact that foreign firms do not conduct much R\&D in developing countries [Lall, 1979; Patel and Vega, 1999; Amsden, Tschang and Goto, 2001]. Therefore, the local workers are trained on how to manufacture the products following the innovations done abroad. Unfortunately, much of this training was on know-how but not know-why. There was also technological learning from quality control practices. The quality control department was very strong and well equipped for analytical purposes. The firm had adopted Total Productive Maintenance (TPM), a Japanese model that allows continuous improvement in quality and management aspects. TMP ensures, total employee involvement, total equipment effectiveness and total absence of wastage. FBF1 was awarded ISO 9001 certification in 2000 for quality management, ISO 14001 certification in 2001 for strict adherence to environmental management and Occupational Health and Safety Assessment Series (OHSAS) 18001 in 2003.

FBF2 was also selected as it utilised processing technologies that were quite sophisticated despite being completely foreign. The implication of this is that the firm did not undertake major process innovation as foreign technical partners were maintained as the sole sources of core processing technology. As a result of high technology used, scale of operation and human capacity possessed, this firm posed stiff competition to the other firms in its sector. The firm enjoyed several bottling lines due to its wide portfolio of alcohol products. We provide an example of a processing technology used in one of FBF2's subsidiaries which manufactures beer. At the time of this research, the firm launched its fourth and the newest investment in quality and capacity. This was a KShs 1.4 billion state-of-the-art bottling line with a filling capacity of 66,000 bottles per hour, making it $200 \%$ more efficient than previous lines. The bottling line manufactured by KHS in Germany was the most modern and according to the production manager only a few breweries in Africa enjoyed such technology in bottling. Accordingly, this process innovation enhanced quality of beer, improved packaging efficiency, reduced beer loss and was more energy conserving. The Germany firm was involved in the installation of the ultra modern bottling line including all the civil work.

The firm contended that investment was not only made in the line and equipment installation, but also on staff training for the new line. Given that the line was more technically advanced than all the previous lines, staff training was extremely inevitable. The plant comprised a highly integrated computer controlled process that required a thorough mastery by local staff in order to operate it. The firm therefore lacked the required skills at the onset to operate it. Experts from KHS Germany were engaged in training the local production staff for several months. The KHS engineers left after the local staff had acquired skills and accumulated the necessary technological capability to manage and operate the bottling line. As explained during the interviews, the production staff spent an estimated 40,000 man-hours training sessions for the bottling new line. The firm contended that the training was aligned to international standards of best practice and once trained; the staff was capable of operating any world-class bottling lines. Locals were introduced to the entire process management (machine operations, trouble shooting procedures, maintenance and safety procedures). This indicated that technological spillovers pertaining to process technology occurred as a result of tremendous training offered by the foreign expatriates. This discussion supports the argument that spillovers of technological learning in firms could equally result from imported technology and machinery as it does from mobility of workers internationally. If these workers later left their jobs with FBF2 to join locally owned firms, the locally owned firms would then 
benefit spillovers as well.

As far as product technology is concerned, the firm acknowledged the importance of innovation and thus undertakes R\&D. As a result of in-house R\&D the firm had acquired enormous product technology which enabled it to manufacture its own brands of alcoholic beverages. As far as product technology was concerned, the staff had learnt and accumulated experience over time as a result of continuous training.

FBF4 was selected as it utilised the most advanced technology to process its products in the fruit processing and packaging sector. Although most of the production technology utilised by FBF4 was fully foreign, some of it was a combination of local and foreign. The firm was operating over $70 \%$ of the total installed capacity. The firm uses a large electronic 'Ginaca' machine for efficient processing of pineapple fruits. Local personnel had been trained and were operating the machinery. The locals had also been trained to operate the sugar recovery plant that was used to extract high-grade refined sugar from waste pineapple skins. At the time of this research, FBF4 had just acquired two new machines, Moeller MCCS, for pineapple processing sourced from South Africa. These machines were capable of removing the fruit skins, wash, slice and can the fruits.

FBF4 has a well-equipped engineering unit (technical workshops) capable of making simple to complicated fabrications. This department was also the custodian of technical equipment used for technical training, which this firm offers. Virtually all the technical operators were Kenyans who had either been trained in-house or externally and had accumulated engineering experience over time while on the job through learning by doing or through interaction either formerly or informally. One of the remarkable innovations of this unit was a massive 120-feet-span boom harvester. Another significant innovation was that of manufacturing fumigants that were more adapted to the local terrain among other local conditions. The department had also introduced many other minor innovations that included mechanical slicers, crushers and sterilizers/coolers. Every modification introduced was tailored to fit the equipment to the local needs. The fabricated equipment were usually more reliable, cost effective and were easily serviceable. A second workshop is also maintained to deal with maintenance and regular servicing of the firm's fleet of motor vehicles and tractors used in the firm. These examples support the argument that locals learnt from the technology and machinery used in the foreign firms. The firm maintains an R\&D unit partly maintained as a laboratory for conducting agronomic tests and as quality control laboratory. The firm had acquired an ISO 9002 quality certification as part of its quality assurance strategy.

FBF5 also utilised quite sophisticated and state-of-the-art bottling lines that were fully foreign for its soft drink production. Most of the machines and technology were sourced from Europe (Germany-France) and partly from South Africa. At the time of this interview, the firm was installing a newly acquired machine equipment expected to improve the production efficiency. Engineers from South Africa were involved in collaboration with the firm engineers, supervisors and technicians. This indicated that with respect to process innovation, the firm did not undertake any innovation. The firm relied on foreign technical partner for the supply of machinery and equipment with guidance from the brand suppliers. Although the firm had a strong foreign technical arrangement for regular maintenance of machinery and technology, it however maintained a separate engineering unit responsible for ensuring smooth processing operations and for undertaking routine repairs and maintenance.

The firm maintained three major sections for the purpose of soft drink manufacture: bottling unit, syrup preparation unit and water treatment unit. The firm enjoyed four fully operational bottling lines. Operations in one of the lines were highly sophisticated with its activities coordinated by a computer-programmed Robot. The Robot could load empty bottles from their crates and place them on the washing line and at the same time remove filled bottles from the filling line and place them into emptied crates for dispatch to the warehouse. In each of these sections different kinds of learning existed. With regard to bottling, locals were trained on all the bottling stages. The staff in the syrup preparation and water treatment section had also learnt a lot by doing and from formal training. The implication of this is that should staff leave in future to join domestic firms, they would share skills and other forms of spillovers of knowledge they have acquired from these trainings.

The firm had no R\&D department. Whenever new products had to be launched, FBF5 relied on the brand suppliers for product innovation and technology. Product R\&D was done abroad, mainly from the MNCs home country. The R\&D done involved improvement of the existing flavours or development of new ones which are then licensed to FBF5. FBF5 however, maintains a well-equipped laboratory with modern analytical capabilities to make sure that the quality of the brands was maintained. The brand suppliers audit the performance of this laboratory, a process that has made the firm improve its production and quality control capability tremendously. Quality control management was monitored through out the entire value added chain. This included standard laboratory for performing normal analytical tests and monitoring efficiency of the entire process. The laboratory 
was therefore manned by highly qualified staff most of whom held degrees in food science, biochemistry or micro-biology. Employees in this department were intensively trained and were all local staff. To ensure quality standards, the department makes sure that the raw materials received were of the expected quality by subjecting them to tests. The ingredients, syrup and microbial tests were done. The bottles were randomly sampled for analysis from the process, filling lines and taken to the laboratory for analysis and examination. The products were also followed in the market for analysis (market survey) just to make sure that they reach the intended customers in the right and expected quality. This ensured that locational variation in, say weather, handling during and after transportation did not affect the initial quality. Although the firm did not have ISO standard, they claimed to follow standards set by the brand suppliers, which were higher than ISO standards. Nevertheless, the firm had quality assurance certification from KEBS.

\subsection{Human Resources Development and Labour Mobility}

This section examines firm level training and labour mobility in the case study firms. Interesting cases of firm training and labour mobility which resulted in spillover occurrence were found.

\subsubsection{Human Resources Development (Firm Training)}

Interstingly, all the foreign firms emphasised the importance of human capital development in their operations. The firms contended that rapidly changing technologies, competition and continuously changing quality control requirements forced them to be conscious of human resources development particularly staff trainings.

Accordingly, the firms had created human resources department with budgets set aside for training purposes including other forms of self-enrichment programmes. The firms studied devoted approximately $10 \%$ of their annual payroll for training purposes. Four forms of trainings were identified during the interviews. In the first case, staff benefited on-the-job training. Secondly, the training was offered in-house but in a training department. Third, the training was offered externally, either in an external training department/institute or in the local training institutes. Finally, training involved external trainings done outside the country (abroad and/or overseas). The firms studied depicted at least more than two of the four forms of training outlined.

FBF1 was a good example of a foreign firm with training policy that reflected all the four forms of trainings outlined. We address each one of them separately. The on-the-job training was the most common form of training witnessed in all the firms studied. It involved all kinds of staff training and differed from firm to firm. However, some kinds of trainings were notable: training on machinery operation and maintenance, safety precautions, how to diagnose trouble shootings, cost and energy saving measures, quality control management.

The second form referred to training done in house and in the firm's own training department. All the firms (FBF1, FBF2, FBF3, FBF4 and FBF5) had well-established in-house training departments where employees underwent staff training. For instance, FBF1 had a separate department for human resource development and training headed by a full director. The department was responsible for identifying the needed capacities and then organise training and other forms of human development needed. This way, the firm offered continuous training at all employment levels with a policy that each employee must attend some form of training at least three times in a year. FBF2 had a human resources department for human development purposes. The employees were therefore subjected to intensive in-house training. External trainers and subject matter specialists were regularly invited to offer trainings in-house. The trainings offered were diverse and could range from quality to process control and management or from individual attitude towards work to market labour conditions and trade disputes. Managers and professionals also attended regular courses on good corporate governance principles and code of best practice. FBF3 and FBF5 had their training designed and supported by their parent companies. FBF5 has a human resources department headed by a human resources manager. Each department has capability heads and section heads below them. By involving the capability heads and section heads, each section conducted skill gap analysis to assess capability needs of their staff. On the basis of the skills gap analysis, appropriate training would then be recommended. The human resource department then takes over and organises for the required training to fill in the required capabilities and to improve existing capabilities. In-house, the firm had a routine schedule of training. Every member of staff had to go through such trainings a few times in a year.

The third form of training identified involved sending staff to the firms' external training departments or to the local training institutions. FBF1 had an organised external training with the local training institutes and business associations. The firm also organises intensive training seminars in secluded places where full board hotel accommodations are organised in different locations from the firm and away from the cities so that everyone fully concentrates in the training conducted without having to leave the premises. This was commonly done with marketing. Due to FBF2 commitment to staff technological training and up-skilling, if certain skills are required, the employees are sent for training, sometimes externally in the local technical training institutions. FBF4 sends 
its employees for training in some of the local training institutions such as Kenya or Mombasa polytechnic. At the time of this interview the firm had over 50 of its staff taking such courses with Kenya Polytechnic. FBF5 sponsors staff to go for external training such as science and technical training courses with national polytechnics. In all the cases studied the staff were allowed to attend regular staff enrichment programmes organised externally say with KAM, KEBs or KIM.

The fourth form of training also included external trainings but this time in the immediate region (regional training institutions) or abroad. Regional training occurred mainly when the parent company decided to have a regional training institute for all its subsidiaries for instance in East and Southern Africa. Exchange programmes also occurred regularly where staff would be sent to the group branches to spend some time for training purposes. All the firms studied sent their staff abroad - mainly technical personnel and professionals for specialized courses or to attend exchange programmes. However, FBF1, FBF3, FBF4 and FBF5 attempted to tap into international resources more prudently by offering trainings internationally with their parent companies as well as through organised exchange programmes. FBF3 had a very elaborate training which included overseas training and regionally coordinated training. In the region, employees were trained within the countries in the region like Zimbabwe and South Africa. Overseas training involved taking staff to Europe and mostly in the groups' headquarters in Switzerland. Senior professionals interviewed (Human resources manager and the Production manager) claimed to have undergone multiple specialised trainings abroad, often Europe (mainly Switzerland, Britain, Germany and Netherlands).

The firm had also an organised exchange programme, where professionals would remain in a different country for sometime ranging from a few weeks to several months undergoing training. For instance, during the interviews, the firm had a visiting production manager from South Africa who would remain there for some months. Experienced engineers and professionals from the firm would even go to train in other countries in the region. The production manager was reported to have traveled to Zimbabwe to conduct technical training. As an exporter, FBF4 asserts a lot of importance in tapping into the global knowledge pool by sending staff for training overseas. Additionally, employees are sent abroad to other affiliates/subsidiaries of the parent MNC firm to acquire practical experience or undertake further training. This is done on a regular basis and every year about five employees are selected to attend the programme. FBF5 employees are also sent for trainings outside the country e.g. with regional training headquarters in Africa. Fortunately, when a South African Brewing Company (SABCO) acquired this firm, training and development of all staff was one of the major priorities. This resulted in the establishment of a regional learning centre in Nairobi, which was officially opened in 2001 with complete conference centre fully equipped with lecture theatres and a separate unit where business simulations could be conducted as part of experiential learning. The regional training centre was supposed to cater for the East African Division which comprised Ethiopia, Kenya, Mozambique, Tanzania and Uganda. This was expected to build entrepreneurial skills for both staff and customers.

The foregoing discussion indicates that all the firms recognised the importance of human resources development in which case they reciprocated by offering training and other forms of staff enrichment programmes. Secondly, and perhaps the most important, was that the foreign firms offered training to the locals which enabled them to operate sophisticated machinery; manage production and other logistics including marketing. In all the companies, local staff had even assumed higher ranks in the management levels in some cases becoming full directors. As an example, FBF4 had an annual assessment policy for human resources and skill development needs that enabled Kenyans to take up senior management posts in the firm. The training programmes offered in this firm had resulted in tremendous human capability development. It is important to emphasise that trainings had often been awarded in line with career development or promotional expectations. The local personnel in this firm had accumulated enough experience over time in both profession and technical aspects. Some of them had become professionals and technical experts with good mastery of their work. In the past two years, the number of expatriate employees had dropped from 20 to 9, all of whom held highly technical or senior management positions. The firm's management generally saw this as an indication of effective transfer of technology by the MNC.

FBF5 had a similar policy to groom in-house senior workers. As an example, two of the main departments were headed by Kenyans who had undergone in house training over time. There were indications that more senior positions were going to be occupied by Kenyans in future. A good example was that of an assistant planner who joined after finishing his A-level studies in 1983. After having worked with the company for 20 years he had been trained, acquired experience and then promoted to the present position of senior assistant planner. As a planner, he was trained on many things ranging from raw material planning to production scheduling. The direct implication of training offered in foreign firms was that when staff leave their jobs with MNCs and later join 
local firms, spillovers are likely to occur.

\subsubsection{Labour Mobility}

The next section attempts to examine labour mobility and opportunities created for spillovers to the domestic firms. From the interviews, it emerged beyond doubt that labour mobility existed between firms. Case study firms had lost and at the same time received workers from other firms. The workers who left could be classified as productive with long standing experience; such included managers and professionals, scientists, engineers and technicians. This was interesting since this category of workers is normally the one associated with generation and diffusion of knowledge. Among the staff that left, many examples were cited where staff had left to join locally owned firms. It was also noted that these firms had acted as breeding grounds for local entrepreneurs. Local people having acquired work experience and training left the firms to start their own firms. We now look at outward and inward mobility of workers separately.

With regard to outward mobility, all the firms studied had lost staff to other firms. For instance, FBF3 indicated it had lost multiple workers to other companies before, which included locally as well as foreign owned firms. Some of the key-manufacturing firms, which benefited skilled employees from FBF3, included FBF2 which benefited engineers from FBF3. Other manufacturing companies included Unga group and FBF1 where they have many workers who joined having worked with FBF3 for several years. Such professionals included marketing and management executives. The recipient firms included not only the manufacturing firms but also firms in the services industry. FBF3 had cases of personnel who equally left but to join the service industry. Nevertheless, the examples provided were of staff that left to join firms in the service industry like Safaricom and Kencell at the managerial and professional levels. At the time of interview these firms were foreign firms. This observation was interesting as it indicated mobility of workers between foreign firms - hence labour mobility wasn't only restricted to the movement of employees from foreign firms to the locally owned firms.

Turning to inward mobility, these firms also received professionals and skilled workers from other firms in the economy - the caliber of these employees included mainly technicians, craftsmen and artisans. For instance, FBF2 had received a few professional workers and skilled engineers from subsidiaries of MNC firms operating in the country. When SABCO - A South African Company - closed its operations in Kenya, FBF2 inherited professionals and most of the technically skilled staff. Similarly, FBF2 received staff from other firms in the service industry. As an example, the group-managing director in 2004 had worked for Standard Chattered Bank Limited, a British owned bank in Kenya, as the Executive Director of Finance responsible for Kenya, Uganda and Tanzania. Having served in this position and in addition to other senior positions in finance department had enabled him to acquire and accumulate invaluable experience in finance and management. He had enjoyed various specialised trainings organised both locally and abroad. He joined FBF2 as the finance and strategy director before being appointed to become the overall group-managing director.

FBF2 also received staff from Guinness International. An example was cited where the previous group manager was from Guinness International. The group finance and strategy director joined from Irish Life PLC where he was the director and chief financial officer. Another example was that of a professional from Guinness UDV who sat in the board of directors and held the group Deputy Chairman Portfolio. As a result of tacit and experiential knowledge acquired while working with $\mathrm{MNC}$, all the people referred to were instrumental in introducing valuable changes pertaining to production, marketing, organisation and management. This example also supports the argument that at least foreign firms in Kenya serve as a 'supply' source of professional expatriates to the local labour market.

FBF4 had equally received staff from other firms. An interesting example was provided of the firm's Chief Executive who was an Italian born but had lived in Kenya since 1972. He was a Ph.D. holder in Business Administration from Florence University and had a degree in Agribusiness Marketing and Management from Harvard Business School, USA. He established an edible oil-processing firm, which was later bought by a locally owned firm. He also helped establish another branch of a MNC dealing with production of breakfast products. When he left this MNC in 1993 he worked as a consultant for private and government Agro-industrial developments in the East African region. This continued until he was appointed as FBF4's Chief Executive in 2000. This example demonstrates knowledge spillovers from mobility of workers in the Kenyan manufacturing industry.

All the above examples supported the argument that labour mobility exists from and within the Kenyan manufacturing industry. The examples also support the argument that mobility of workers leaving their jobs with MNC affiliates can result in spillovers of knowledge given that the staff considered here were managers and professionals and technically skilled personnel. Many firms indeed contended that as a result of immense 
training offered and experiential tacit knowledge accumulated on-the-job, such workers resulted to spillovers of knowledge to the firms hiring them with possible accumulation of technological capability. Nevertheless, this needs further investigation from the angle of the local firms. It was noted that those who left their jobs were attracted by high salaries offered to them by the receiving firms in other sectors of the economy or competing firms in the manufacturing industry.

\subsection{Linkage Effects}

We attempted to map out and examine linkages formed by each of our case study firms. We also examined interactions between these firms and other systems of innovation such as business associations, public and private institutions. We identified both pecuniary and non-pecuniary forms of linkages. Pecuniary linkages seemed more dominant than the non-pecuniary linkages. This was however expected given that most of the subsidiaries in food and beverages industries were technology users.

The firms considered in our case studies contended that demand created and purchases made helped spur growth, investment and expansion to locally owned firms as it provided them with capital. To the foreign firms the feed back obtained through these linkages were important in that they helped them introduce changes on their processes, products and even marketing techniques. For example, FBF4 has developed good backward linkages with some sectors of the economy. Metal cans for pineapple packaging, for instance, are produced at an adjacent company, while cartons, labels, spare parts and provisions for the cannery and plantation are purchased from various domestic manufacturers. With over 5,000 employees, FBF4 was a major economic force within Thika town, one of Kenya's major industrial towns. The economy of the town is closely tied to the performance of FBF4.

Non-pecuniary linkages identified included linkages with the firms in the machine and engineering industry (user-supplier relationships). However, given that the firms relied on foreign suppliers for their core production technology, local technical links with locally owned firms were only limited to maintenance, repairs and sale of simplified machine and engineering equipment. An appropriate analysis of the two kinds of linkages could not be undertaken due to data constraint. Firms did not have or did not want to disclose data, which would enable us to examine trends in any kind of linkages and thus we just present a general qualtitative discussion. We make no effort to separate the two kinds of linkage in our discussion. From the angle of foreign firms, local firms seemed to have acquired skills and spillovers of knowledge through the linkages formed and existing interactions. They audit their local suppliers (FBF4) regularly. They are involved in offering training to appointed co-packers of their products especially in food safety and marketing operations and advertising services. They are also involved in fixing prices for the co-packers. FBF4 has a local company, which does packaging for it. The firm stations some of its experienced personnel there to oversee the operations. These personnel have offered training in the locally owned firm, quality control and production management.

In addition to the linkages mapped, we also identified interactions with the local support systems such as business associations, private and public institutions such as $\mathrm{R} \& \mathrm{D} / \mathrm{academic}$, financing institutions and government regulatory organisations and enforcement agencies. Through these interactions, skills and knowledge were shared, including technical assistance. We provide a few examples here. All the firms (FBF1, FBF2, FBF3, FBF4 and FBF5) were very active members of Kenya Association of Manufacturers (KAM). For instance, the chief executives of FBF1 and FBF4 were board members of KAM where they shared their expertise. The executive committee members of the KAM comprised chief executive officers from some of these firms (FBF3, FBF1 and FBF4). The managing director of FBF3 was the chairman of food and beverages sector. The Chief Executive Officer of FBF1 was the chairman of the social, legal and regulatory committee while the chief executive of FBF4 was the chairman of the industrial linkages committee charged with stimulating collaboration, linkages and strategic alliances in the industry. It is interesting to note that all the Chief Executives were foreigners who in their capacities definitely shared their wide experience through their participation. This could include labour ethics, corporate governance, policy lobbying technique, intellectual property rights etc.

Some of the firms also interacted with the Marketing Society of Kenya (MSK). The mission of MSK is to "project, promote and uphold marketing as a vital ingredient for success and prosperity." Two of MSK's council members were drawn from FBF1 and FBF5. Through MSK, annual competitions open to firms in the industry or services are free to enter. The competition categories involve best launch for new products or services, marketing effort and strategies, best innovation of product brands or services, best development of existing product brands etc. Through these competitions firms exchanged skills and ideas. Another institution that firms interacted with was Kenya Institute of Management (KIM). Firms participated in their annually organised Company Of the Year Award (COYA). Firms compete in various categories such as sound financial 
management, innovativeness and creativity, quality management, environmental management and information management and marketing management. FBF2 was a several times winner of the COYA award.

Similarly, all firms interacted with government regulatory bodies such as Kenya Bureau of Standard (KEBS), Federation of Kenya Employees (FKE) and Monopolies and Prices Department. For instance, all the firms interacted with FKE for labour issues and disputes. Also, all firms participated in the development of standards with KEBS. They needed to achieve Kenya Quality Award (KQA) as well as Diamond Mark of Quality all awarded by KEBS. KEBS in collaboration with SGS awards ISO 900 series for implementation of Quality Management Systems (QMS) and ISO 14000 certification for implementation of Environmental Management Systems (EMS). KEBS also organises for quality competitions for the award of Kenya Quality Award (KQA) FBF1 was a winner of KQA. Other memberships included Kenya Institute of Research and Development Institute (FBF1), with Kenya Dairy Processors Association (FBF3), Kenya Industrial Property Institute (FBF2) and local micro financial institutions (FBF5) etc.

On technology development the country lacks strong R\&D to support industry innovation and technology development, as there was little involvement of universities research work in industrial activities. The firm had to rely on external sources for innovation and technology development. Nevertheless, the firms participate in human capital development in the country. Firms (e.g. FBF2) offer competitive academic scholarship to students pursuing higher education. The firms offer industrial attachment annually where graduates from local universities and polytechnics can have their industrial attachment. The firms sometimes offer jobs to the best candidates after completion of their industrial attachment and degree programmes. NBF4 contended that it worked closely with the University of Nairobi by offering internship and later absorbed some graduates in food science technology. FBF4 offers technical assistance in a unique way. It works closely with the Government's Management Training and Advisory Centre, the Directorate of Industrial Training and Kenya Polytechnic in developing its training programmes. The firm's full-time training manager organises internal courses, which are supplemented by the on-going local management programmes conducted by reputable local firms. At any time, about 40 students are enrolled in trade and technical apprenticeship programmes. The company is usually able to retain about $80 \%$ of its apprentices, with the rest being absorbed by other industries.

The discussion on linkage effects supports the following conclusions: First, linkages do exist between the foreign firms and locally owned firms. Second, linkages also exist between foreing firms and other actors in the systems of innovation such as business associations, public andprivate instiruions. Lastly, tremendous knowledge spilovers occurred which had a possibility of learning and capability accumulation.

\subsection{Competition Effects}

In this section, we analyse the existing competition between foreign firms and locally owned firms. In the sector considered, MNCs and locally owned firms competed fiercely with each other. Nevertheless, due to the dominant position of foreign firms with regard to their scale of operation and technological capability, foreign firms often out-competed the domestic firms sometimes triggering them to upgrade by introducing necessary changes. Specifically, foreign firms triggered learning processes and technological changes in the locally owned firms.

In order to appreciate how competition from foreign presence might have forced the locally owned firms to engage in the learning process, our discussion in this section will address four observations made in the course of doing this research. These were: mode of entry by some of the locally owned firms, formation of joint venture, international competition and high technology and capital equipment investment. All the firms (both foreign and domestic) faced stiff competition from imported goods into the country. The open market operations following liberalisation opened up doors to all kinds of imported goods resulting in an influx of imports particularly from COMESA and SADAC region e.g. South Africa.

In order to understand how mode of entry led to increased competition we discuss experience of FBF1 and FBF3. The two firms were among the most competitive MNC subsidiaries in food and beverages processing industry. The two firms also competed for market in certain goods such margarine. FPF2's competitiveness was largely attributed to a large pool of skilled workers backed up by strong human resource development, innovation backed up by in-house R\&D and in-turn supported by the parent company, adherence to strict quality, environment and safety management systems, Total Preventive Maintenance (TPM) and efficient delivery of services. Similarly, FBF3 source of competitiveness was due to more or less the same attributes: economies of scale, strict quality management systems, human resources development, and process and product technology with support from the parent company. Consequently, the two firms had an absolute edge over local firms. However, since the introduction of structural adjustments (SAPS) in Kenya in the late 1980s, FBF1 and FPF4 
have continued to face severe competition from new entrants as well as from new products resulting in a substantial decline of the two firms' market shares.

The competition has been based on innovation with regard to new market, products and services delivery. The locally owned firms capitalised on an existing window of opportunity in the domestic and regional market. Based on their local market intelligence, they learnt that the MNCS products were expensive and thus targeted for high-income group. The entry strategy by the locals in the sector therefore targeted the middle level group with relatively cheap brands and thus captured a big share of these firms' market. FBL1 is an example of a locally owned firm that made its entry targeting the middle income level group.

Many changes took place in this sector, apart from introduction of cheap brands, the sector for the first time changed containers used in packaging cooking fat and margarine to plastic containers. This happened when FBF1, for instance, was still using metal tin containers. FBF1 was forced to adopt the Kenyan version of its parent company's global strategy aimed at reducing its brands worldwide. Following this strategy, FBF1 whose brand portfolio was over 30 brands had to reduce them to only 10 leading brands that are well known in the domestic and the immediate regional market. Interestingly, this strategy resulted in FBF1 selling its edible oil and cooking fat product line to its local rival, FBL1. This product which was one of the FBF1's flagship brand, with an annual turnover of US \$25.0 million was acquired together with other brands of cooking fat, and laundry soap. The selling of product and processing technology to the local firm represented a typical example of technological spillover as a result of foreign presence. This was so since the domestic firm did not have to engage in any search effort through R\&D. On their side, both firms (FBF1 and FBF3) have increased their advertisement levels. FBF1 has since increased its advertisement level to an annual expenditure of about US $\$ 1.2$ million making the company rank among the top in the country with the highest advertising expenditure. The firm has launched a strong campaign of re-launching its products to create awareness and attract more customers. It has intensified its trainings and adoption of quality management systems and occupational health and safety analysis system (OHSAS). All these are done with the facilitation by the parent company.

Similarly, due to competition pressure, FBF3 has adopted various techniques particularly in marketing. As in FBF1, this firm has started re-launching its flagship products done in line with and following a major international re-launch policy of parent firm products organised from the headquarters in Switzerland. The re-launching is innovatively done to contain a particular theme for instance illustrated by competitive sports depicting its uniqueness of the product as an energy giving drink. To further product promotion campaigns, FBF3 holds a corporate horse racing day in Kenya with an objective to create exposure for the firm's products and to interact with its product consumers, business partners and colleagues. It also involves itself in physical education (PE) lessons of some schools similarly meant to promote the firm's products to the youth. Other skills employed in the marketing include branding policy where small promotional items such as caps, mugs, T-shirts, pens, pencils etc, are offered for sale or given out. This, however, must comply with the parent company's marketing and safety policy requirements. From the information gathered, the firm can invest up to an average of KShs 0.5 million for the purpose of a single product re-launch. As the production personnel claimed, FBF3 was still a leader virtually in all aspects of production in its sector and locally owned firms were followers with lots of things to learn from FBF3. The firm claimed that the quality management system were above ISO quality standards.

Another interesting point to illuminate here is that the changes implemented by the foreign firms' in-turn created intensive competition to the locally owned firms. Following the foreign firms' strategies to regain or expand their market the domestic firms loses their market. Hence the domestic firms would have to equally undertake strategies to counteract the competition pressure from the foreign presence. The bottom line of this discussion is that competition in this sector headed by the foreign firms' presence serves as a trigger for the learning process and introduction of technological changes.

Next we consider a unique case where entry by a MNC subsidiary from South Africa into the beer processing industry created stiff competition for the incumbents who had enjoyed monopoly for several decades. As expected, the incoming MNC subsidiary was characterised by high product and state-of-the-art processing technology. They had high skills in corporate management coupled with international exposure with well-established links. This firm's entry into the sector recorded one of the highest capital investment to have ever been made in the brewing industry. What makes this case particularly fascinating is the fact the pressure introduced forced the one of the local incumbents to form a joint venture. The formation of a joint venture in-turn helped transform the firm from loss making to profit making and becoming one of the most efficient firms with sound management and employing state-of-the-art machinery. Subsequently, the firm created intense competition to the other locals especially in the wines and spirits sectors such FPL2. This helped them to engage 
in the learning process.

Another interesting case, which we discovered, involved effect of international competition in the fruit-processing industry. FBF4 was involved in processing and export of canned fruits to the European market for a long time. This created a window of opportunity in the local and regional market, which locally owned firms were exploiting. Unfortunately, due to international business cycles, there was a decline in international demand that resulted in stiff international competition for the European market. FBF4 faced stiff competition from Asian countries that were able to offer cheap products to Europe. Due to the increased international competition, FBF4 decided to look for alternative market domestically and in the immediate regional trading blocks. Consequently, this created intensive domestic competition for the market, which has forced locally owned firms to learn, introduce drastic changes in mechanization to their processes and adoption of quality systems.

Finally, we discuss a case where MNC subsidiaries in the soft drink industry creates intensive competition by making huge investment in capital machinery and equipment coupled with vast product diversification with strong support by the parent company. The emanating competition pressure forced the locals in the sector to look for alternative means of survival some resulting to establishment of international linkages for support in product and process technology. All these cases supported the spill over occurrence in teh conxtext of competition effects.

\subsection{Demonstration Effects}

Investigation of demonstration effects indicated that all the foreign firms studied had demonstration effects which created opportunities for spillover occurrence to the locally owned firms. Foreign firms indicated that locally owned firms had copied, imitated products and production techniques from them. We now present individual firm accounts of demonstration effects, which stimulated technological spillovers.

FBF1 claimed that domestic firms had introduced new products and production techniques taken after them. The domestic firms were able to make similar but own products implying they had learnt and accumulated the necessary capabilities. As an example, FBF1 were the pioneers in the mechanised production and supply of cooking fat and edible oil, margarines, and finally washing soaps and detergent in the country. FBF1 started its operations in the country before the country attained its independence. Local firms used to make hand made soap but in the course of time they introduced and adopted mechanised process of making soap. This was confirmed by Langdon (1978) study which noted that local firms adopted mechanised soap production techniques similar to that used by the MNC subsidiaries in the country.

Similarly, local firms have started producing cooking fat, edible oils and margarine in a similar way to FBF1. The case of margarine was particularly exciting in that a domestic firm used the same model and technique as in FBF1 in its processing, promotion and marketing. In actual fact, FBF1 had a case in court with this particular domestic firm claiming that it had imitated and used a component of its margarine trademark. According to FBF1, the local firm was packaging its margarine using the "same shape and colour, configuration, design and general appearance that had an integral part of its trade mark". FBF1 has therefore served to increase the portfolio of products and has thus reduced the product search process for the local firm. FBF1 was also the first company to engage the services of a separate promotion, logistics and delivery. This served as demonstration to other firms both local and foreign who started using similar services. Use of such services triggered organisational, management and marketing changes. This case supports the argument that MNCs can bring new knowledge, management and marketing skills where local firms observe them and imitate them. Some of the firms have started exporting.

Another area in which locally owned firms were observed to have enjoyed demonstration effects was in staff training. As a result of ensuing competition, the locally owned firms have been stimulated to embrace firm training as done in most foreign firms. Another demonstration effect comes in the area of quality management. The foreign firms were usually the first in acquiring quality assurance standards after which the locally owned firms followed. As an example, FBF1 and FBF3 were among the first foreign firms to have obtained an ISO. FBF3 was explained to have the best quality control in Africa in culinary industry. FBF1 was also the first to achieve OHSAS. When the foreign firms acquired international quality standard they also enjoyed expanded export market as a result of high quality assurance. In this case we can argue that foreign firms demonstrates not only quality standards but also export market.

FBF5 claims to have many demonstration effects to the local firms. Similarly, FBF5 has also enjoyed from demonstration effects from competing firms. As an example, the firm started a strong campaign to diversify. For instance, the firm ventured into the manufacture of non-carbonated drinks and started bottling of mineral water 
and fruit juices. Demonstrations enjoyed by the domestic firms from FBF5 included processing techniques, product technology, organisation and marketing strategies. We provide a few examples. The first example includes use of micro-finance programme to support distributors. The domestic competing firms have now imitated this programme and have initiated similar programmes backed by strong campaigns to solicit for funding from various sources. FBF5 also contended that local competitors had also copied the use of container method used by their distributors. FBF5 claimed to have been the pioneers of this process as a marketing strategy. We provide another example of how demonstration effects can stimulate spillovers in domestic firms. Since FBF5 follows marketing strategies designed by the brand owners (USA soft drink MNC), it therefore changes the style of its marketing and advertising often. At the time of this research, FBF5 was venturing into a new advertising campaign following the new marketing strategy launched by the brand owners in the United States. It would include new advertising campaign, strong music and digital components, promotions, properties, one-to-one marketing initiatives and new packaging and graphics. The advertising component featured radio, television, on line, print, cinema and outdoor executions. From time to time it would also include participation in sponsorship of certain activities. Such marketing strategies present a lot of learning to the domestic firms. However, this is only useful if it does not re-allocate resources away from learning to innovate in the local firms.

Finally we provide an example from FBF4. As will be shown the local firms started manufacturing and packaging of fruit juices in the same style as FBF4. Other local firms have even started packaging other wide ranging juices such as passions, orange, mangoes etc. Learning from FBF4, a few domestic firms including FBL4 have started exporting in the region. As a conclusion to this section, it can be argued that spillovers occurred as a result of demeontration effect in the industry studied. Given the observed cases, we can sum that demonstration effects posited equally excellent cases of spillover occurrence.

\section{Conclusions and Policy Implications}

This paper examined learning and technological change from foreign firms focusing on only five cases studies in the Kenyan context. Although this may have been ambitious, it is however warranted by the need to understand the role FDI plays in engendering technical change and capability development particularly in the African context. The literature has been treated to a plethora of empirical studies which hardly exposes the actual mechanism of spillover occurrence.

The case studies have been very illuminating. Conceptualising spillovers in terms of learning and capability building, we conclude that FDI stimulates spillover occurrence. However, this finding cannot be generalised due to the heterogeneity of industries. The implication of these findings is that through spillover occurrence, FDI plays an important role in enhancing technological learning and capability building.

\section{Acknowledgement}

The author would like to acknowledge with thanks the release time support from University of Dubai to work on this paper. Initial financial support by UNU-MERIT is greatly acknowledged.

\section{References}

Aghion, P., \& Howitt, P. (1990). A Model of Growth through Creative Destruction. Economica, 60(2), 323-351.

Aitken, B., \& Harrison, A. (1992). Does Proximity to Foreign Firms Induce Technology Spillovers? Mimeo, World Bank and International Monetary Fund.

Aitken, B., \& Harrison, A. (1999). Do Domestic Firms Benefit from Direct Foreign Investment? Evidence from Venezuela. The American Economic Review, 89(3), 605-618. http://dx.doi.org/10.1257/aer.89.3.605

Altomonte, C., \& Pennings, E. (2009). Domestic plant productivity and incremental spillovers from foreign direct investment. Journal of International Business Studies, 40(7), 1131-1148. http://dx.doi.org/10.1057/jibs.2008.99

Amsden, A., Tschang, T., \& Goto, A. (2001). Do Foreign Companies Conduct R\&D in Developing Countries? A New Approach to Analyzing the Level of $R \& D$, with an Analysis of Singapore. ADB Tokyo, Asian Development Bank Institute.

Arrow, K. J. (1962). The Economic Implications of Learning by Doing. Review of Economic Studies, XiX. http://dx.doi.org/10.2307/2295952

Behrman, J., \& Wallender, H. (1976). Transferring of Manufacturing Technology within Multinational Enterprises. Cambridge, Massachusetts, Ballinger.

Belderbos, R., \& Capannelli, G. (2001). Backward Vertical Linkages of Foreign Manufacturing Affiliates: 
Evidence from Japan Multinationals. World Development, 29(1). http://dx.doi.org/10.1016/S0305-750X(00)00086-3

Blomstrom, M., \& Kokko, A. (2003). Human Capital and Inward FDI. CEPR Discussion Papers 3762, CEPR. Discussion papers.

Blomstrom, M., \& Persson, H. (1983). Foreign Investment and Spillover Efficiency in an Underdeveloped Economy: Evidence from the Mexican Manufacturing Industry. World Development, 11(6), 493-501. http://dx.doi.org/10.1016/0305-750X(83)90016-5

Caves, R. (1974). Multinational Firms, Competition and Productivity in Host-Country Markets. Economica, 41(162), 176-93. http://dx.doi.org/10.2307/2553765

Caves, R. (1982). Multinational Enterprise and Economic Analysis. New York: Cambridge University Press.

Cheung K., \& Lin, P. (2004). Spillover effects of FDI on innovation in China: Evidence from the Provincial data. China Economic Review, 15(1), 25-44. http://dx.doi.org/10.1016/S1043-951X(03)00027-0

Crespo, N., \& Fontoura, M. (2007). Determinant factors of FDI spillovers - What do we really know? World Development, 35(3), 410-425. http://dx.doi.org/10.1016/j.worlddev.2006.04.001

Das, S. (1987). Externalities and Technology Transfer through Multinational Corporations: A Theoretical Analysis. Journal of International Economics, 22(1-2), 171-182. http://dx.doi.org/10.1016/0022-1996(87)90028-6

Dunning, J. (1973). The Determinants of International Production. Oxford Economic Papers, 25(3), 289-336.

Dunning, J. (1993). Multinational Enterprises and the Global Economy. Addison-Wesley Publishing Company.

Ernst, D., Mytelka, L., \& Ganiatsos, T. (1998). Technological Capabilities in the Context of Export-Led Growth: A conceptual Framework, in D. Ernst, T. Ganiatsos \& L. Mytelka (Eds.) Technological Capabilities and Export Success in Asia. London: Routledge.

Fosfuri, A., Motta, M., \& Ronde, T. (2001). Foreign Direct Investment and Spillovers through Workers' Mobility. Journal of International Economics, 53(1), 205-222. http://dx.doi.org/10.1016/S0022-1996(00)00069-6

Fransman, M. (1985). International Competitiveness, Technical Change and the State: The Machine Tool Industries in Taiwan and Japan. World Development, 14(12), 1375-1396. http://dx.doi.org/10.1016/0305-750X(86)90038-0

Gachino, G. (2006). Foreign Direct Investment, Spillovers and Innovation. The case of Kenyan manufacturing Industry. Ph.D. Published Thesis, University of Maastricht.

Gachino, G. (2010a). Technological Spillovers from Multinational Presence: towards a conceptual framework. Progress in Development Studies, 10(3), 193-210. http://dx.doi.org/10.1177/146499340901000301

Gachino, G. (2010b). Foreign Direct Investment and Firm Level Productivity in Kenyan Manufacturing: A panel Data Analysis. International Journal of Institutions and Economies, 2(1), 17-57.

Gerschenkron, A. (1962). Economic Backwardness in Historical Perspective. Cambridge, Havard: University Press.

Gershenberg, I. (1987). The Training and Spread of Managerial Know-How, A Comparative Analysis of Multinational and Other Firms in Kenya. World Development, 15(7), 931-939. http://dx.doi.org/10.1016/0305-750X(87)90043-X

Giroud, A., \& J. Scott-Kennel (2007). Foreign-Local Linkages and Spillovers in International Business. Academy of International Business Conference United Kingdom and Ireland, London, 13-14 April.

Glass, A., \& Saggi, K. (2002). Mutlinational Firms and Technology Transfer. Scandinavia Journal of Economics, 104(4), 495-514. http://dx.doi.org/10.1111/1467-9442.00298

Görg, H., \& Greenaway, D. (2004). Much Ado About Nothing? Do Domestic Firms Really Benefit from Foreign Direct Investment? World Bank Research Observer.

Görg, H., Hijzen, A., \& Muraközy, B. (2009). The role of production technology for productivity spillovers from multinationals: Firm-level evidence for Hungary. Aussenwirtschaft, 64(1), 19-44.

Griliches, Z. (1979). Issues in Assessing the Contribution of Research and Development to Productivity Growth. The Bell Journal of Economics, 10(1), 92-116. http://dx.doi.org/10.2307/3003321

Hansen, N. (2002). Dynamic externalities and spatial innovation diffusion: Implications for peripheral regions. 
International Journal of Technology Policy and Management, 2(3), 260-271.

Haskel, J., Sonia, E., Pereira, C., \& Slaughter, M. (2007). Does inward foreign direct investment boost the productivity of domestic firms? Review of Economics and Statistics, 89(3), 482-496. http://dx.doi.org/10.1162/rest.89.3.482

Hirschman, A. (1958). The Strategy of Economic Development. New haven: Yale University Press.

Hymer, S. (1960). The International Operations of National Firms: A Study of Direct Foreign Investment. Massachusetts, Published 1976 Cambridge, Massachusetts: MIT Press.

Inzelt, A. (2008). The inflow of highly skilled workers into Hungary: A by-product of FDI. Journal of Technology Transfer, 33(4), 422-438. http://dx.doi.org/10.1007/s10961-007-9053-z

Javorcik, B. (2004). Does Foreign Direct Investment Increase the Productivity of Domestic Firms? In search of Spillovers through Backward Linkages. American Economic Review, 93(3), 605-627. http://dx.doi.org/10.1257/0002828041464605

Javorcik, B., \& Spatareanu, M. (2008). To share or not to share: Does local participation matter for spillovers from foreign direct investment? Journal of Development Economics, 85(1-2), 194-217. http://dx.doi.org/10.1016/j.jdeveco.2006.08.005

Kim, L. (1997). Imitation to Innovation: The Dynamics of Korea's Technological Learning. Boston Massachusetts: Harvard Business School Press.

Kim, L. (1999). Learning and Innovation in Economic Development. Massachusetts, Cheltenham; Edward Elgar Publishing, Inc.

Kneller, R., \& Pisu, M. (2007). Industrial linkages and export spillovers from FDI. World Economy, 30(1), 105-134. http://dx.doi.org/10.1111/j.1467-9701.2007.00874.x

Kravtsova, V. (2008). Foreign presence and efficiency in transition economies. Journal of Production Analysis, 29(2), 91-102. http://dx.doi.org/10.1007/s11123-007-0073-3

Lall, S. (1979). Multinationals and Market Structure in an Open Developing Economy: The Case of Malaysia. Weltwirtschaftliches Archiv, 115(2), 325-350. http://dx.doi.org/10.1007/BF02696333

Lall, S. (1987). Learning to Industrialise: The Acquisition of Technological Capability by India. London: Macmillan Press.

Lall, S. (1996). Learning from the Asian Tigers: Studies in Technology and Industrial Policy. London \& New York: Macmillan Press Ltd \& St. Martin's Inc.

Lall, S., \& Streeten, P. (1977). Foreign Investment, Transnational and Developing Countries. Basingstoke: Macmillan.

Marcin, K. (2008). How does FDI inflow affect productivity of domestic firms? The role of horizontal and vertical spillovers, absorptive capacity and competition. Journal of International Trade and Economic Development, 17(1), 155-173. http://dx.doi.org/10.1080/09638190701728131

Marshall, A. (1890). Principles of Economics. An Introductory Volume. London: Macmillan.

Meyer, E., \& Sinani, E. (2009). When and where does foreign direct investment generate positive spillovers? A meta-analysis. Journal of International Business Studies, 40(7), 1075-1094. http://dx.doi.org/10.1057/jibs.2008.111

Muraközy, B. (2007). Do vertical spillovers from FDI lead to changes in markets? Firm-level evidence from Hungary. Applied Economics Quarterly, 53(2), 197-218.

Pack, H., \& Saggi, K. (1997). Inflows of Foreign Technology and Indigenous Technological Development. Review of Development Economics, 1(1), 81-98. http://dx.doi.org/10.1111/1467-9361.00007

Patel, P., \& Vega, P. (1999). Patterns of Internationalisation of Corporate Technology: Location vs. Home Country Advantages. Research Policy, 28(2-3), 145-155. ttp://dx.doi.org/10.1016/S0048-7333(98)00117-6

Rasiah, R. (2003). Systemic Coordination and the Knowledge Economy: Human Capital Development in MNC-driven Electronics Clusters in Malaysia. Transnational Corporations, 11(3), 89-130.

Rasiah, R. (2005). Foreign Firms, Technological Capabilities and Economic Performance: Evidence from Africa, Asia and Latin America. Edward Elgar, UK: Edward Elgar Publishing.

Rasiah, R., \& Gachino, G. (2005). Are Foreign Firms more Productive and Export and Technology Intensive 
than Local Firms in Kenyan Manufacturing. Oxford Development Studies, 33(2): 211-227. http://dx.doi.org/10.1080/13600810500137855

Rodriguez-Clare, A. (1996). Multinationals, Linkages, and Economic Development. American Economic Review, $86(4), 852-873$.

Romer, P. (1986). Increasing Returns and Long Run Growth. Journal of Political Economy, 94(5), 1002-1037. http://dx.doi.org/10.1086/261420

Romer, P. (1990). Endogenous Technological Change. Journal of Political Economy, 98(5), S71-102. http://dx.doi.org/10.1086/261725

Ruane, F., \& Ali U. (2004). Foreign direct investment and productivity spillovers in Irish manufacturing industry: Evidence from plant level panel data. International Journal of the Economics of Business, 11(3), 53-66.

Schumpeter, J. (1934). The Theory of Economic Development. Oxford: Oxford University Press.

Schumpter, J. (1952). Capitalism, Socialism, and Democracy. London: Unwin.

Scott-Kennel, J. (2007). Foreign direct investment and local linkages: An empirical investigation. Management International Review, 47(1), 51-77. http://dx.doi.org/10.1007/s11575-007-0004-6

Sinani, Evis \& Klaus E. Meyer. (2004). Spillovers of technology transfer from FDI: The case of Estonia. Journal of Comparative Economics, 32(3), 445-466. http://dx.doi.org/10.1016/j.jce.2004.03.002

Smarzynska, B. (2003). Does Foreign Direct Investment Increase the productivity of Domestic Firms? In Search of Spillovers through backward Linkages. William Davidson Institute WP No 548.

UNCTAD. (2001). World Investment Report: Promoting Linkages. New York, Geneva, United Nations Conference on Trade and Development.

Wang, C., \& $\mathrm{Li} \mathrm{Yu,} \mathrm{(2007).} \mathrm{Do} \mathrm{spillover} \mathrm{benefits} \mathrm{grow} \mathrm{with} \mathrm{rising} \mathrm{foreign} \mathrm{direct} \mathrm{investment?} \mathrm{An} \mathrm{empirical}$ examination of the case of China. Applied Economics, 39(3), 397-405. http://dx.doi.org/10.1080/00036840500428096

Wang, J., \& Blomstrom, M. (1992). Foreing Investment and Technology Transfer: A Simple Model. European Economic Review, 36(1), 137-155. http://dx.doi.org/10.1016/0014-2921(92)90021-N 